\title{
Association of endothelin-1 with oxidative stress and inflammatory response in pre-hypertensives
}

\author{
Niranjan Gopala , Nachimuthu Maithilikarpagaselvib , Anitha Rajendiran”, \\ Abu Raghavan Srinivasan ${ }^{b}$, Pruthu Gowdac, Veni Subramanyam ${ }^{d}$
}

a Department of Biochemistry, All India Institute of Medical Sciences (AIIMS), Nagpur, Maharashtra, India

${ }^{b}$ Department of Biochemistry, Mahatma Gandhi Medical College and Research Institute, Pondicherry, India

' Department of Community Medicine, Mahatma Gandhi Medical College and Research Institute, Pondicherry, India

${ }^{d}$ Central Interdisciplinary Research facility, Mahatma Gandhi Medical College and Research Institute, Pondicherry, India

\section{ARTICLE INFO}

\section{Article history:}

Submitted: 27. 12. 2018

Accepted: 27. 3. 2019

Available online: 25. 11. 2019

Klíčová slova:

Endotelin-1

Kyselina sialová vázaná na lipidy

LDL-C

Malondialdehyd

Prehypertenze

\section{SOUHRN}

Úvod: Hypertenze je jedním z hlavních rizikových faktorů rozvoje kardiovaskulárních onemocnění. U osob s prehypertenzí existuje vyšší pravděpodobnost progrese k hypertenzi. Mechanismus progrese prehypertenze do hypertenze zůstává nejasný. Naše studie byla proto navržena s cílem prozkoumat vztah mezi endotelinem-1 na jedné straně a oxidačním stresem a zánětlivou reakcí na straně druhé u jedinců s prehypertenzí. Metody: Do studie bylo zařazeno 30 osob s prehypertenzí a 30 normotenzních jedinců. Ve vzorcích krve odebraných nalačno se stanovoval lipidový profil a hodnoty kyseliny sialové vázané na lipidy (lipid-bound sialic acid, LBSA), malondialdehydu (MDA) a endotelinu-1 (ET-1).

Výsledky: Hodnoty celkového cholesterolu, triglyceridů (TG), cholesterolu lipoproteinů o velice nízké hustotě (very low-density lipoprotein cholesterol, VLDL-C) i cholesterolu lipoproteinů o nízké hustotě (low-density lipoprotein cholesterol, LDL-C) byly u osob s prehypertenzí statisticky významně zvýšené. U jedinců s prehypertenzí byly ve srovnání s normotoniky nalezeny i zvýšené hodnoty LBSA $(39,58 \pm 4,35)$, ET-1 $(13,43 \pm 5,1)$ a MDA $(1,78 \pm 3,5)$. U osob s prehypertenzí hodnoty ET-1 statisticky významně korelovaly s hodnotami LBSA a MDA. Analýza křivky ROC pro hodnoty ET-1, LBSA a MDA prokázala mezní hodnoty 7,0, resp. 31,5 a 1,23 pro stanovení diagnózy prehypertenze.

Závěr: Zvýšené hodnoty ET-1, LBSA a oxidačního stresu jsou spojeny se změnou krevního tlaku u osob s prehypertenzí, která může následně progredovat do esenciální hypertenze.

(c) 2019, ČKS.

\section{ABSTRACT}

Introduction: Hypertension represents the major risk factor for cardiovascular diseases. Pre-hypertensives are more likely to progress to hypertension. The mechanism for the progression of pre-hypertension to hypertension remains unclear. Hence the present study was designed to investigate the association of endothelin-1 with oxidative stress and inflammatory response in pre-hypertensives.

Methods: The study was conducted in thirty subjects with pre-hypertension and thirty normotensive subjects. Lipid profile, lipid bound sialic acid (LBSA), malondialdehyde (MDA) and endothelin-1 (ET-1) levels were estimated in the fasting blood samples.

Results: Total cholesterol, triacylglycerol (TAG), very low density lipoprotein cholesterol (VLDL-c) and low density lipoprotein cholesterol (LDL-c) were significantly increased in pre-hypertensives. LBSA $(39.58 \pm 4.35)$, ET-1 (13.43 \pm 5.1$)$ and MDA $(1.78 \pm 3.5)$ were also significantly elevated in pre-hypertensives when compared to normotensive subjects. ET-1 was significantly correlated with LBSA and MDA in pre-hypertensives. Receiver operating curve analysis of ET-1, LBSA and MDA showed cut off values of 7.0, 31.5 and 1.23 respectively for the diagnosis of pre-hypertension.

Conclusion: Elevated ET-1, LBSA and oxidative stress are associated with altered blood pressure in pre-hypertensives and may progress to essential hypertension.
Keywords:

Endothelin-1

LDL-c

Lipid bound sialic acid

Malondialdehyde

Pre-hypertension 


\section{Introduction}

Systolic blood pressure greater than $120 \mathrm{mmHg}$ and less than 139 and diastolic blood pressure (DBP) greater than $80 \mathrm{mmHg}$ and less than 89 are defined as pre-hypertension. ${ }^{1}$ Pre-hypertension is most prevalent in developed as well as in developing countries. Pre-hypertensives increases the risk of developing essential hypertension twice when compared to normotensive individuals. Nearly one billion individuals are affected with essential hypertension and expected to reach 1.56 billion by $2025 .^{2}$ Hypertension is associated with cardiovascular disease and accounts for $24 \%$ coronary heart diseases in India. ${ }^{3}$ Dyslipidemia, oxidative stress and inflammatory response play an important role in the pathogenesis of hypertension and predictive factors for cardiovascular diseases. ${ }^{4}$ The enhanced production of free radicals is associated with a decline in the antioxidant status and this imbalance leads to oxidative stress. Increased oxidative stress further augments the activation of inflammatory proteins and exacerbates the inflammatory status. Many clinical and experimental studies have shown that hypertension is associated with oxidative stress. ${ }^{5-7}$ Chrysohoou et al. have documented the association of pre-hypertension with oxidative stress and dyslipidemia independently of other co-existing factors. ${ }^{8}$

Endothelial dysfunction is a characteristic of hypertension associated with atherosclerosis and is considered as an early feature in atherogenesis. ${ }^{9}$ Systemic inflammation induces oxidative stress and endothelial dysfunction that play a significant role in the clinical manifestation of cardiovascular disease. Factors contributing to hypertension along with oxidative stress and inflammation may be the production of endothelin-1. Endothelin-1 is a peptide produced by vascular endothelium and has very potent systemic vasoconstricting properties and attributes to elevated blood pressure. ${ }^{10}$ Further epidemiological, experimental and clinical studies indicated the presence of endothelial dysfunction in hypertensive subjects. ${ }^{11}$ Saito et al. have documented the relationship between ET-1 levels and essential hypertension suggesting the causative role for ET-1 in the pathogenesis of the disease. ${ }^{12,13}$ But the association between endothelial dysfunction, oxidation stress and systemic inflammation in the development of pre-hypertension remains clear. Hence the present study was designed to investigate the association of endothelin-1 with oxidative stress and inflammatory response in pre-hypertensives.

\section{Materials and methods}

This study was conducted in the Department of Biochemistry in collaboration with Department of General Medicine, Mahatma Gandhi Medical College and Research Institute, SBV, Pillaiyarkuppam, Puducherry. The study was conducted after obtaining the permission from institutional research council and institute human ethics committee (IHEC). Blood pressure was measured using a mercury sphygmomanometer and average of the three values was recorded as the actual blood pressure of the volunteer's.

The study comprises of two groups, normotensive (healthy control) and pre-hypertensive groups with thir- ty subjects in each. Thirty subjects having systolic blood pressure greater than $120 \mathrm{mmHg}$ and less than 139 and diastolic blood pressure (DBP) greater than $80 \mathrm{mmHg}$ and less than 89 were included in pre-hypertensive group. Systolic blood pressure $<120 \mathrm{~mm} \mathrm{Hg}$ and diastolic blood pressure $<80 \mathrm{~mm} \mathrm{Hg}$ were included in normotensive group. Subjects with history of hypertension, diabetes mellitus, coronary artery disease, known organ dysfunction, present smokers and chronic alcoholics and individuals suffering from any other endocrine disorders were excluded from the study.

\section{Sample collection}

Three millilitre of venous blood samples were collected in EDTA vial after an overnight fasting of 12 hours. The blood samples were centrifuged at $3000 \mathrm{~g}$ for $10 \mathrm{~min}$ and the plasma was separated. Lipid profile such as total cholesterol (TC), triacylgycerol (TAG) and high-density lipoprotein (HDL) cholesterol were estimated immediately using kits adapted to clinical chemistry autoanalyser. Very low-density lipoprotein (VLDL) cholesterol was calculated using the formula (TAG/5). Low-density lipoprotein (LDL) cholesterol was calculated using the Friedewald formula $[T C-(H D L+V L D L)] .{ }^{14}$ Endothelin-1 was estimated using ELISA method and procured kit from UBI Magiwell, California, USA. Plasma Lipid bound sialic acid (LBSA) and malondialdehyde Aminoff's method ${ }^{15}$ and method of Yagi et al. ${ }^{16}$ respectively.

\section{Statistical analysis}

All data are expressed as mean \pm standard deviation. Independent ' $t$ ' test was used to find the significant difference among the two groups. Pearson's correlation analysis was done to find the association between the biochemical parameters. Receiver operating curves (ROC) were done to find the sensitivity and specificity of biochemical parameters for predicting pre-hypertension in normotensive individuals. Statistical analysis was proved using Statistical Package of Social Service (SPSS), Version 19.0.

\section{Results}

Table 1 shows the baseline characteristics of the subjects. There was no significant difference between the age, BMI and waist to hip ratio. SBP $(125 \pm 5.4)$ and DBP $(85 \pm 6.2)$

\begin{tabular}{|l|l|l|}
\hline \multicolumn{3}{|l|}{ Table 1 - Basic characteristic of subjects } \\
\hline Parameter & Control $(\mathbf{n}=\mathbf{3 0})$ & Pre-hypertensive $(\mathbf{n}=\mathbf{3 0})$ \\
\hline Age (years) & $36.4 \pm 7.0$ & $38.2 \pm 10.0$ \\
\hline BMI $\left(\mathrm{kg} / \mathrm{m}^{2}\right)$ & $22.5 \pm 4.4$ & $24.9 \pm 3.5$ \\
\hline Waist to hip ratio & $0.89 \pm 0.03$ & $0.92 \pm 0.04$ \\
\hline SBP $(\mathrm{mmHg})$ & $112 \pm 3.0$ & $125 \pm 5.4^{*}$ \\
\hline DBP $(\mathrm{mmHg})$ & $70 \pm 5.5$ & $85 \pm 6.2^{*}$ \\
\hline
\end{tabular}

BMI - body mass index; DBP - diastolic blood pressure; SBP - systolic blood pressure.

Data are expressed as mean \pm SD.

The parametric data were compared by using unpaired student's $t$ test. * Statistically significant compared to other group, with $p$ value $<0.05$. 


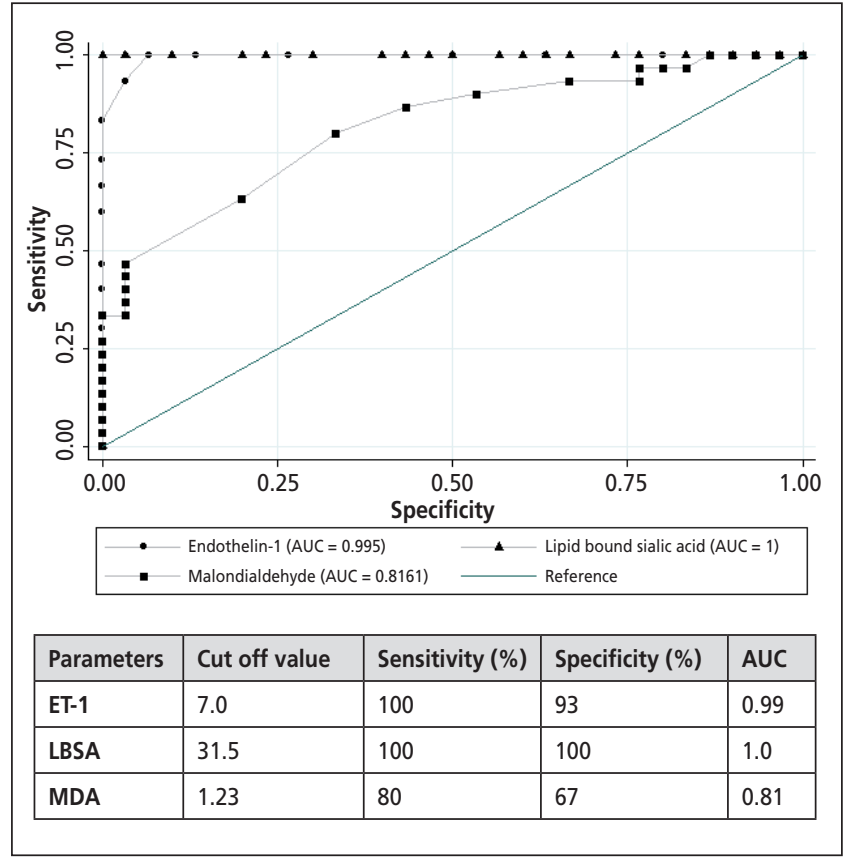

Fig. 1 - ROC of endothelin-1, lipid bound sialic acid and malondialdehyde for the diagnosis of pre-hypertension.

were significantly increased in pre-hypertensives when compared to control.

Comparison of mean \pm SD of the lipid bound sialic acid, malondialdehyde, endothelin-1 and lipid profile of normotensive and pre-hypertensive are shown in Table 1. Lipid bound sialic acid (LBSA) and malondialdehyde (MDA) levels were significantly elevated in prehypertensives when compared to normotensive subjects. Similarly endothelin-1 was also significantly elevated in pre-hypertensive when compared to control. Total cholesterol $(246.5 \pm 6.61)$, triacylglycerols $(129 \pm 13.8)$. Very low-density lipoprotein $(25.8 \pm 2.74)$ and low-density lipoprotein $(181.8 \pm 9.24)$ were significantly increased in pre- hypertensives when compared to control. No significant change was found in HDL-c among the two groups.

Receiver operating characteristic curve for ET-1, LBSA and MDA are shown in Figure 1. Area under the curve of the Receiver operative curve (ROC) of ET-1, LBSA and MDA was found to be $0.99,1.0$ and 0.81 respectively. The optimal cut off values of ET-1, LBSA and MDA were 7.0 (100\% sensitivity and $93 \%$ specificity), 31.5 (100\% sensitivity and $100 \%$ specificity) and 1.23 ( $80 \%$ sensitivity and $67 \%$ specificity) respectively.

Figure 2 shows the association of circulating ET-1 levels with lipid bound sialic acid and malondialdehyde levels. ET-1 was positively correlated with lipid bound sialic acid $(r=0.79, p<0.001)$ and MDA $(r=0.75, p<0.001)$ in Prehypertensives.

\section{Discussion}

Hypertension is becoming a serious threat to human health and positively associated with cardiovascular disease. The Seventh Report of the Joint National Commit-

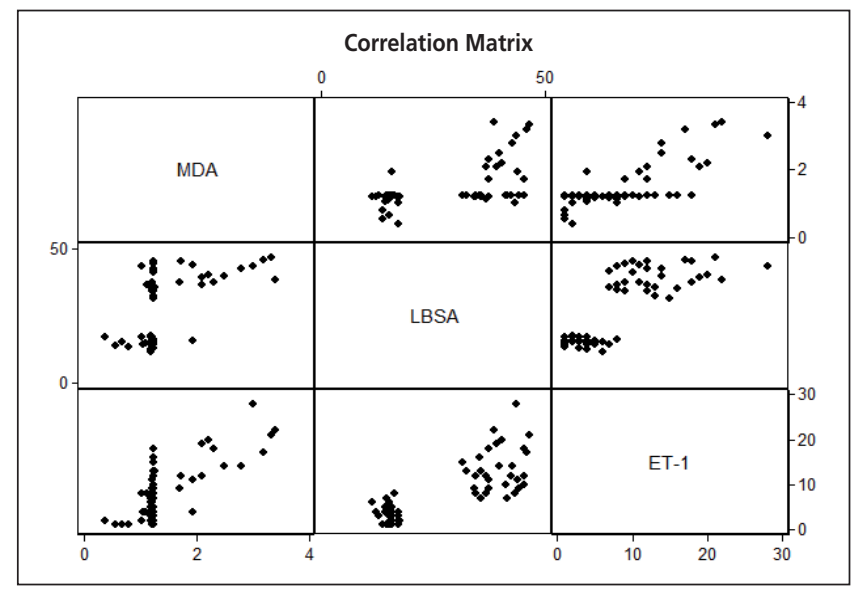

Fig. 2 - Correlation between endothelin-1, LBSA and MDA

Table 2 - Comparison of serum lipids, MDA, LBSA and ET-1 levels between the normotensives and subjects with pre-hypertension

\begin{tabular}{|l|l|l|l|l|}
\hline Parameters & Normotensives $(\mathbf{n = 3 0 )}$ & \multicolumn{2}{l}{ Pre-hypertensive subjects $(\mathbf{n}=30)$} \\
\hline & Mean \pm SD & $95 \%$ Cl & Mean \pm SD & 95\% Cl \\
\hline LBSA $(\mu \mathrm{g} / \mathrm{mg}$ of protein) & $15.26 \pm 1.49$ & $14-15$ & $39.58 \pm 4.35^{*}$ & $38-41$ \\
\hline ET-1 $(\mathrm{pg} / \mathrm{mL})$ & $3.44 \pm 1.90$ & $3-4$ & $13.43 \pm 5.10^{*}$ & $11-15$ \\
\hline MDA $(\mu \mathrm{mol} / \mathrm{L})$ & $1.14 \pm 0.26$ & $1-2$ & $1.78 \pm 3.5^{*}$ & $1-2$ \\
\hline TC $(\mathrm{mg} / \mathrm{dL})$ & $163.7 \pm 21.28$ & $156-172$ & $246.5 \pm 6.61^{*}$ & $244-249$ \\
\hline TAG $(\mathrm{mg} / \mathrm{dL})$ & $116 \pm 14.18$ & $111-122$ & $129 \pm 13.8^{*}$ & $124-134$ \\
\hline VLDL $(\mathrm{mg} / \mathrm{dL})$ & $23.3 \pm 2.83$ & $22-24$ & $25.8 \pm 2.74^{*}$ & $24-26$ \\
\hline LDL-c $(\mathrm{mg} / \mathrm{dL})$ & $79.90 \pm 25.19$ & $70-89$ & $181.8 \pm 9.24^{*}$ & $178-185$ \\
\hline HDL-c $(\mathrm{mg} / \mathrm{dL})$ & $43.34 \pm 10.7 *$ & $39-47$ & $41.4 \pm 3.54$ & \\
\hline
\end{tabular}

$\mathrm{Cl}$ - confidence interval; ET-1 - endothelin-1; HDL-c - high density lipoprotein-cholesterol; LBSA - lipid bound sialic acid; LDL-c - low density lipoprotein-cholesterol; MDA - malondialdehyde; SD - standard deviation; SE - standard error of mean; TAG - triacylglycerols; TC - total cholesterol; VLDL - very low density lipoprotein.

The parametric data were compared by using unpaired student's t test.

* Statistically significant compared to other group, with $p$ value $<0.001$. 
tee (JNC 7) describes prehypertension as an independent category of blood pressure. ${ }^{17}$ Studies have demonstrated that pre-hypertension precedes the development of hypertension in $90 \%$ of people and also increase the risk of cardiovascular disease. ${ }^{18-20}$ It has been reported that patients with elevated blood pressure are more susceptible for the advancement of overt hypertension, cardiovascular disease and its associated complications when compared to normotensive subjects. Hence the identification of the risk factors or the markers for the early detection of pre-hypertension before the development of essential hypertension would be of great significance in preventing the cardiovascular risk.

There are many reports showing increased pro-atherogenic lipid profile, resulting in increased cardiovascular events. Abnormalities in lipid metabolism may be another important contributory factor in the pathogenesis of hypertension. Consistent with this, total cholesterol (246.5 $\pm 6.61)$, triacylglycerol $(129 \pm 13.8)$, very low-density lipoprotein $(25.8 \pm 2.74)$ and low-density lipoprotein (181.8 \pm 9.24 ) were significantly increased in pre-hypertensives when compared to control. No significant change was found in HDL-C among the two groups. These findings were in concordance with the results shown by Sathiyapriya et al. ${ }^{21}$ Similarly another study has shown the lipid derangements in pre-hypertensives compared to healthy subjects. ${ }^{22}$ It has been reported that higher TC, TAG, LDL-C and non HDL-c have been found to be associated with an increased risk of hypertension which supports the findings of our study.

Sialic acid is an acute-phase protein which is a component of oligosaccharide and abundant in vascular endothelial cells. Elevated sialic acid is associated with cardiovascular morbidity and mortality. In the present study, lipid bound sialic acid (LBSA) was significantly elevated in pre-hypertensives. This suggested that LBSA has been increased before the development of hypertension which could be used as early marker for the prediction of hypertension and risk of cardiovascular complications. The ROC cut off value for LBSA was 31.5 with sensitivity $100 \%$ and specificity $100 \%$ for the diagnosis of pre-hypertension in the present study. Increased levels of LBSA indirectly reflect the inflammatory response observed in this study. Elevated sialic acid also accelerates atherosclerosis and enhances the clot formation in vascular endothelium perhaps due to inflammatory response..$^{22}$

In the present study lipid peroxidation product, malondialdehyde is significantly elevated in subjects with prehypertension when compared to control. It was concordance with previous study which shows the increased MDA level in pre-hypertensive subject. ${ }^{23}$ The optimum cut off value for MDA was found to be 1.23 with $80 \%$ sensitivity and $67 \%$ specificity in this study. Increased inflammatory response due to elevation of sialic acid leads to oxidative stress that would have resulted in the elevation of lipid peroxidation products, malondialdehyde. Oxidative stress is reflected as one of the risk factors for the onset of hypertension and its associated complications. Mounting evidence indicates that oxidative stress is directly related to endothelial dysfunction. Oxidative stress may cause endothelial dysfunction, vascular damage and associated with pre-hypertension or essential hypertension.
Endothelin-1 (ET-1) is a vasoconstrictor peptide, abundant in vascular endothelium and smooth muscle cells. Many experimental and clinical studies have shown the association between endothelin levels and hypertension. ${ }^{4,24}$ In accordance with this we also found elevated levels of ET-1 in pre-hypertensive subjects when compared to normotensives which show that elevation of ET-1 occurs in the circulation well before the development of overt hypertension. This finding was consistent with the previous literature. ${ }^{25}$ The optimal cut off values of ET-1 was 7.0 with $100 \%$ sensitivity and $93 \%$ specificity which is a better marker for the prediction of pre-hypertension when compared to MDA which has $80 \%$ sensitivity and $67 \%$ specificity when compared to ET-1. In the present study we have shown that ET-1 was positively correlated with lipid bound sialic acid and MDA. Elevated ET-1 reveals the endothelial dysfunction in pre-hypertension in this study and concordance with the previous study. ${ }^{26}$ Increased circulating levels of sialic acid indirectly reflect the inflammatory response in pre-hypertension which is also associated with oxidative stress. The inflammatory response and oxidative stress observed in this study may promote the oxidation of LDL via endothelial dysfunction, cause the vascular wall damage and ultimately culminate in atherosclerosis in future. This may be partially attributed to variations in blood pressure, plasma cholesterol, TAG and lipoproteins in pre-hypertensives. Indeed pre-hypertensive subjects have increased risk for the development of overt hypertension and cardiovascular diseases in future. Hence ET-1, LBSA and MDA levels could be used as adjunct markers for the early diagnosis of prehypertension and cardiovascular risk.

\section{Conclusion}

Our findings confirm the presence of inflammation and oxidative stress in pre-hypertensives as evidenced by elevation of lipid bound sialic acid and malondialdehyde levels. In addition endothelial dysfunction marker, endothelin-1 and atherogenic lipid profile are significantly elevated in pre-hypertensives which may contribute to elevation of blood pressure in a patient with pre-hypertension. These could be used as early marker for the assessment of endothelial dysfunction and cardiovascular risk in pre-hypertension and also helps in the prevention of progression to essential hypertension and early management of the same.

\section{Conflicts of interest}

There are no conflicts of interest.

\section{Acknowledgements}

We thank to Mahatma Gandhi Medical College and Research Institute (MGMCRI) for providing the infrastructure required for the study.

\section{References}

1. Martin JF, Martin LN, Cipullo JP. Pharmacologic treatment for prehypertension: to treat or not to treat? Recent Patents Cardiovasc Drug Discov 2009;4:133-141. 
2. Kearney PM, Whelton M, Reynolds K, et al. Global burden of hypertension: analysis of worldwide data. Lancet Lond Engl 2005;365:217-223.

3. Bureau M. Hypertension causes half of all stroke deaths in India [Internet]. Medi Bull. 2018 [cited 2018 May 28]. https:// medibulletin.com/hypertension-causes-half-of-all-strokedeaths-in-india/

4. Dhaun N, Goddard J, Kohan DE, et al. Role of endothelin-1 in clinical hypertension: 20 years on. Hypertension 2008;52:452459.

5. Lacy F, Kailasam MT, O'Connor DT, et al. Plasma hydrogen peroxide production in human essential hypertension: role of heredity, gender, and ethnicity. Hypertension 2000;36:878884.

6. Saraswathi R, Sankar D, Ali A, et al. A pilot assessment of oxidative stress byproducts and antioxidant activities among Indian patients with various stages of hypertension. Clin Exp Hypertens 2011;33:437-443.

7. Tanito M, Nakamura H, Kwon Y-W, et al. Enhanced oxidative stress and impaired thioredoxin expression in spontaneously hypertensive rats. Antioxid Redox Signal 2004;6:89-97.

8. Chrysohoou C, Panagiotakos DB, Pitsavos C, et al. The association between pre-hypertension status and oxidative stress markers related to atherosclerotic disease: the ATTICA study. Atherosclerosis 2007;192:169-176.

9. Berneis KK, Krauss RM. Metabolic origins and clinical significance of LDL heterogeneity. J Lipid Res 2002;43:13631379.

10. Yanagisawa M, Kurihara H, Kimura $\mathrm{S}$, et al. A novel potent vasoconstrictor peptide produced by vascular endothelial cells. Nature 1988;332:411-415.

11. Taddei S, Virdis A, Ghiadoni L, et al. Endothelial Dysfunction in Hypertension. J Cardiovasc Pharmacol 2001;38:S11.

12. Saito $Y$, Nakao K, Mukoyama M, Imura H. Increased plasma endothelin level in patients with essential hypertension. $\mathrm{N}$ Engl J Med 1990;322:205.

13. Xu M, Lu YP, Hasan AA, Hocher B. Plasma ET-1 Concentrations are Elevated in Patients with Hypertension - Meta-Analysis of Clinical Studies. Kidney Blood Press Res 2017;42:304-313.

14. Friedewald WT, Levy RI, Fredrickson DS. Estimation of the concentration of low-density lipoprotein cholesterol in plasma, without use of the preparative ultracentrifuge. Clin Chem 1972;18:499-502.
15. Aminoff $D$. Methods for the quantitative estimation of $\mathrm{N}$-acetylneuraminic acid and their application to hydrolysates of sialomucoids. Biochem J 1961;81:384-392.

16. Yagi K. Assay for blood plasma or serum. Methods Enzymol 1984;105:328-331.

17. Chobanian AV, Bakris GL, Black HR, et al. The Seventh Report of the Joint National Committee on Prevention, Detection, Evaluation, and Treatment of High Blood Pressure: the JNC 7 report. JAMA 2003;289:2560-2572.

18. Greenlund KJ, Croft JB, Mensah GA. Prevalence of Heart Disease and Stroke Risk Factors in Persons With Prehypertension in the United States, 1999-2000. Arch Intern Med 2004;164:2113-2118.

19. Huang $Y$, Wang $S$, Cai $X$, et al. Prehypertension and incidence of cardiovascular disease: a meta-analysis. BMC Med 2013;11:177.

20. Vasan RS, Larson MG, Leip EP, et al. Assessment of frequency of progression to hypertension in non-hypertensive participants in the Framingham Heart Study: a cohort study. Lancet Lond Engl 2001;358:1682-1686.

21. Sathiyapriya V, Selvaraj N, Nandeesha H, et al. Association between protein bound sialic acid and high sensitivity C-reactive protein in prehypertension: a possible indication of underlying cardiovascular risk. Clin Exp Hypertens 2008;30:367-374.

22. Jinghua $L$, Tie $Z$, Ping $W$, Yongtong $C$. The relationship between serum sialic acid and high-sensitivity $C$-reactive protein with prehypertension. Med Sci Monit Int Med J Exp Clin Res 2014;20:551-555.

23. Nakkeeran M, Periasamy S, Inmozhi SR, et al. Increased Levels of Inflammatory Marker hsCRP, MDA and Lipid Profile in Non-obese Hypertension Subjects. Biochem Anal Biochem. 2017;6:1-4.

24. Leung JWC, Wong WT, Koon HW, et al. Transgenic mice over-expressing ET-1 in the endothelial cells develop systemic hypertension with altered vascular reactivity. PloS One 2011;6:e26994.

25. Weil BR, Westby CM, Greiner JJ, et al. Elevated endothelin-1 vasoconstrictor tone in prehypertensive adults. Can J Cardiol 2012;28:347-353.

26. Iglarz M, Clozel M. Mechanisms of ET-1-induced endothelial dysfunction. J Cardiovasc Pharmacol 2007;50:621-628. 